AperTO - Archivio Istituzionale Open Access dell'Università di Torino

\title{
Current perspectives in food-based studies exploiting multi-omics approaches
}

\section{This is a pre print version of the following article:}

Original Citation:

\section{Availability:}

This version is available http://hdl.handle.net/2318/1623879

since 2018-01-03T14:06:34Z

Published version:

DOI:10.1016/j.cofs.2017.01.002

Terms of use:

Open Access

Anyone can freely access the full text of works made available as "Open Access". Works made available under a Creative Commons license can be used according to the terms and conditions of said license. Use of all other works requires consent of the right holder (author or publisher) if not exempted from copyright protection by the applicable law. 
1 Current perspectives in food-based studies exploiting multi-omics approaches

2

3

4

5

6

7

8

9 Abstract

10

11

12

13

14

15

16

17

18

19

Addresses

\section{Abstract}

\section{Highlights} 5

Corresponding author: Ilario Ferrocino (ilario.ferrocino@unito.it)

\section{Ilario Ferrocino*, Luca Cocolin}

DISAFA - Microbiology and food technology sector, University of Turin, Grugliasco, Torino, Italy

The new frontiers of microbial ecology are concerned pertain to what microbes are do in a complex ecosystem, such as food, and how the environmental conditions (e.g changes in the process parameters, storage temperature, the addition of a starter culture and changes in ingredients) can affect the development and functioning of microbiota. A multi-omics approach can help researchers 7 to obtain an unprecedented insight into the mechanisms that can affect the final characteristics of products, in term of organoleptic proprieties, as well as safety.

- Bioinformatics tools have been developed to provide information on microbe diversity

2 - Shotgun metagenomics is a promising approach to discover the functions of microbiota

3 - Data generated through a multi-omics approach can improve the knowledge on what happens in food 
Next-generation sequencing and metagenomics were first used in microbial ecology in the second decade of the 2000s. At present, a search on the ISI Web of Knowledge on the topics "metagenomics" and "food" shows the presence of 660 research papers, with less than 90 per year before 2013, a peak of 132 in 2015 and 109 in the first 10 months of 2016. This exponential increase in studies is due to the greater availability of sequencing centers with competitive prices, along with a growing population of scientists with a good background in bioinformatics and biostatistics, as well as the development of online platforms that allow a huge amount of data to be analyzed, even by inexperienced researchers. The term metagenomics is a miscellaneous term that is often misused by many researchers. Metagenomics is the appropriate term for a shotgun approach in which all the genome contents from the matrix are sequenced (host, gene fragments of taxonomic interest, as well as functional genes); instead, if a taxonomic region is massively sequenced (16S, ITS or 26S), the term that should be used is amplicon based sequencing. The first decision that a researcher has to make is whether to adopt global or live high throughput sequencing (HTS). This is the crucial issue that has to be resolved before starting an experiment, since the use of DNA or rRNA as targets can lead to both advantages and disadvantages. DNA is more stable and easier to extract and manipulate, but a DNA experiment displays the global microbial population, including DNA from dead and damaged cells, as well as from live cells, with the consequence that a researcher will not be able to discern whether the microbiota is still alive and active or dead at a specific sampling point. The decision to use RNA as a target eliminates this bias, because RNA, after cell lysis, is less stable than DNA, and allows the analysis to be focused only on live and active microbiota [1]. On the other hand, the disadvantage of using rRNA as a target is the amplification of ribosomal genes, due to the operon copy number, which varies widely across the taxa, and can even distort the quantitative diversity estimates [2]. Another possible way of detecting live populations is through the use of the DNA of ethidium monoazide (EMA) and propidium monoazide (PMA), which can prevent the amplification of DNA from dead cells. 
53 Increased data analysis skills can allow the study of microbial composition (amplicon target sequencing), gene content (meta-genomics), gene function (meta-transcriptomics), functional activity (meta-proteomics) and metabolites (meta-metabolomics) to be joined together. The huge amount of data generated through a multi-omics approach can improve the knowledge on what really happens in a complex process, such as in the food fermentation process, or in general during a process that involves microbes.

\section{High-throughput amplicon target sequencing.}

61

The first and most frequently applied HTS technique is the application of amplicon target sequencing to the microbial composition of a food matrix in order to study the microbiota (targeting the $16 \mathrm{~S}$ gene) or the mycobiome (targeting the ITS or the $26 \mathrm{~S}$ gene) of the food. The flurry of research has been witnessed over the past couple of years aimed at estimating the microbial diversity in different dairy ecosystems using 16S DNA as the target. Several studies on food have clearly shown the presence of several contaminant taxa, probably originating from the environment, which can play a role in the decay of food quality. However, the main objective of all of these studies has been to assess the microbial structure of the analyzed product in order to find a correlation between the external perturbations (e.g. changes in the process, ingredients and sampling point) and the evolution of the microbial composition. Table 1 reports an extensive, although not complete, list of these studies.

In the targeted amplicon technique, the most common approach adopted to study the mycobiome is that of amplifying the fungal "internal transcribed spacer" (ITS) regions. Since these ITS regions are not part of the conserved transcribed regions of the structural ribosomal RNAs, they are highly divergent between fungi, and are often sufficiently different to allow the fungi to be classified at species level. The locus in fungi is generally duplicated 100-200 times, thus caution must be used when trying to derive quantitative comparisons between various species in mixed populations through this approach. First, unlike bacterial 16S amplicons, fungal ITS sequences from different 
species can differ to a great extent in size and sequence content [28]. ITS fragments generally vary in length from between 100 and 550 base pairs, and it is not yet clear how the variable lengths affect the recovery of sequences through the various steps of sequencing on high-throughput platforms. In addition, there is no well-established database of ITS sequences. The publicly available repositories of fungal sequences are replete with redundant sequences containing incomplete and/or incorrect taxonomic assignments [29]. Most fungi show high interspecific variability in the variable D1/D2 domain of large subunit (26S) ribosomal DNA [30], and sequencing appears most robust because strain comparisons can easily be made. Recent studies [11,29-32] have indicated that the use of the D1/D2 region of the 26S rRNA gene, using NL1 primers to investigate the fungal distribution in the samples, appears to be the most robust approach. However, more work still needs to be done to implement and make a database, such as Greengenes, available for $16 \mathrm{~S}$.

Only a few papers have been aimed at understanding what the microbiota really does in a food matrix by coupling HTS with other techniques, thus representing complete and comprehensive studies. Interesting results have been obtained from these studies, and they clearly show that only a few taxa really play important roles during the food process, and that it is only by coupling different techniques that it is possible to study complex food ecosystems. In addition, one of the important questions that need to be addressed, once the microbiota composition has been evaluated, is how this microbiota (in most cases a few taxa) can affect the final characteristics of the products. One possible approach is to couple the HTS-amplicon based approach with metabolomics (both targeted and untargeted) to create a tool that can be used to identify the potential candidate metabolites (biomarkers) related to specific taxa [33].

\section{Bioinformatic tools to translate sequences into data for interpretation purposes}

Recently, several tools have been developed to use the data from amplicon base sequencing as input and to analyze these data so as to provide information on the diversity of the microbes. Network 
analysis [34••] has emerged as an important tool that can be used to easily observe the structure and dynamics of microbes, from an interactive point of view of the microbiota distribution, which can also be used for food process development. Gephi or Cytoscape software can help scientists to visualize data and to easily extract information about the development or the interaction of the microbiota in the samples. Foodmicrobionet (http://www.foodmicrobionet.org/fmbn1_0_3web/) is a recently developed application that collects data from multiple food-based studies with the aim of 111 allowing an easy and visual-effective comparison of one's own samples with several others from 112 the same food environment $[34 \bullet \bullet]$.

113 Amplicon-based sequencing is a key tool for studies on microbial communities, but does not 114 provide direct evidence on a community's functional capabilities. An easy way of getting an idea of 115 the potential function of the microbial community is to use a computational approach to predict the 116 functional composition of a metagenome, using marker gene data and a database of reference 117 genomes. PICRUSt (phylogenetic investigation of communities by reconstruction of unobserved 118 states) shows that the phylogenetic information contained in $16 \mathrm{~S}$ marker gene sequences is 119 sufficiently well correlated to the genomic content to provide an accurate prediction of the gene 120 repertoires, associated with their microbiota [35]. The main application of this tool is to 121 environmental samples, however, in food associated studies, the tool has been found to be able to 122 find correlations among taxa and metabolic functions associated with spoilage $[5,7]$.

123 Another promising NGS data analysis method relies on the use of oligotyping, a novel supervised 124 computational method that can elucidate concealed diversity from within the final operational units 125 of classification or clustering approaches. Unlike clustering methods, which compare all the 126 positions in sequence reads to assess similarity, oligotyping utilizes the nucleotide positions that 127 have been identified as the most information-rich, and allows resolution at a species level or even 128 below [36]. Till now, only human-based and environmental studies have used this tool to identify 129 sub-OTU level differences across samples [37], or to track changes in specific populations across 130 seasons and geography [38]. However, this tool can also be easily applied to food based studies in 
order to ascertain an association between an oligotype and a process, or to have a better idea of the distribution of a specific taxon in a food-based system.

\section{Who is there and what are they doing?}

135 The shotgun metagenomic approach (DNA-seq or RNA-seq) is a valuable approach that is applied 136 extensively to environmental microbiology, but which is also of increasing interest in food microbiology. The main purpose of this technique is to obtain, at the same time, information about the microbe composition and the gene content without any PCR bias. Interest in the shotgun RNAseq approach, applied to food matrix, is growing, due to its ability to discover the functions of microbes during a food process. This technique has recently been applied to cheese matrices in order to find differences in gene expression associated with a particular ripening time [39], to select biological markers in order to improve cheese quality assessment [40], or just to assess the microbial physiology during cheese manufacturing [41,42]. The main problem of using RNA-seq 144 alone is the lack of availability of genome sequences to map the reads, and the need to couple them 145 to DNA-seq data and to the amplicon-based HTS data, which results in an increase in the cost of 146 sequencing. The use of the shotgun DNA-seq approach is interesting, because it provides higher147 resolution taxonomic information than 16S rRNA sequencing and can profile hundreds of 148 uncharacterized species, especially those present in low abundances, and at the same time obtain 149 information about the gene content from a global point of view. The main application in food 150 concerns the possibility of detecting foodborne pathogens in a food matrix $[43,44]$, or of 151 understanding the change in the gene content during a process [45-48]. A possible application of 152 DNA-seq concerns the possibility of performing a de novo extraction of strains from metagenomes. 153 Pangenome [49] is used extensively in epidemiology studies with the aim of analyzing strain154 specific gene sets, and of providing a comprehensive view of the functional and pathogenic 155 potential of the organisms. When reference genomes are included in the analysis, it is also possible 156 to compare different strains or to identify new ones. This tool is promising for food ecologists, and 
can easily be applied to food systems in a variety of ways, such as the selection of species/strains

158 for starter cultures, or the discovery of possible associations between a specific strain and a process 159 point. The increase in scientists' bioinformatic skills, the availability of online tools to analyze data 160 (e.g. MG-RAST, Galaxy) and the increase in the number of pipeline applications, such as 161 PanPhlAn [50] or Anvio's [51], all allow the huge amount of data produced with/through the 162 shotgun metagenomic approach to be analyzed.

\section{Multi-Omics Approach}

Most of the studies based on NGS just give a partial representation of the food-based ecosystem, because only one of the techniques is applied, and a final remark, such as "...needs further study ...", is often added. In the authors' opinion, this is probably due to the cost of the experiment or the need for different specialties, which are generally lacking in a single research unit. Only a few examples that combine different omics approaches have been found for food. Dugat-Bony et al. have recently shown an example in which data from metagenomic, metatranscriptomic and 171 biochemical analyses have been combined to obtain a complete view of what really happens during

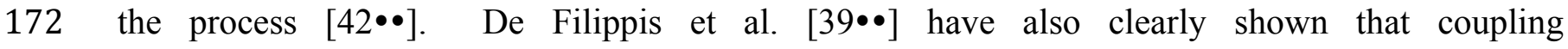
metatranscriptomic and metabolome data is effective in discovering the functional diversity of 174 cheese microbiota affected by different ripening conditions. Coupling the genetic potential and 175 final phenotype to, for example, metabolomics and metaproteomics, which is also called 176 proteogenomics [52], can offer the possibility of resolving the main functional components that 177 drive the function of the microbial ecosystem [53]. Proteogenomics can in particular offer the 178 possibility of exploring the microbial function, although metagenomics analysis can detect the presence of different bacterial species and genes, metaproteomics can/is able to provide information on the most representative metabolic pathways that are active during the food process [54]. 
184 At the moment, several tools are available to help one really understand what happens in a food185 based system. Unfortunately, only a few examples of multi-omics approaches are available in the 186 literature and these approaches need to be implemented to obtain a better understanding of food 187 microbial ecosystems. However, this approach also suffers from certain limitations, due to its 188 relatively high cost and the need for specific bioinformatics and biostatistics skills for the data 189 analysis. 


\begin{tabular}{|c|c|c|c|}
\hline Target & Short description & Food matrix & Referen \\
\hline 16S DNA & $\begin{array}{l}\text { Bacterial diversity of Salame Piacentino } \\
\text { PDO during ripening }\end{array}$ & Meat & [3] \\
\hline 16S RNA (cDNA) & Piedmontese fermented meat during ripening & Meat & [4] \\
\hline 16S RNA (cDNA) & $\begin{array}{l}\text { Beef burger (controls or with added } \\
\text { preservatives, nisin }+ \text { EDTA) vacuum packed }\end{array}$ & Meat & [5] \\
\hline 16S DNA & Vacuum-packaged, cooked sausage & Meat & [6] \\
\hline 16S DNA & Fresh beef and pork cuts & Meat & [7] \\
\hline 16S DNA & Fresh and spoiled meat and seafood samples & Meat/fish & [8] \\
\hline 16S DNA & $\begin{array}{l}\text { Chicha, a maize-based fermented beverage } \\
\text { from Argentina }\end{array}$ & Fermented beverages & {$[9]$} \\
\hline 16S DNA & French organic sourdoughs & Doughs & [10] \\
\hline $\begin{array}{l}\text { 16S RNA (cDNA)/16S } \\
\text { DNA }\end{array}$ & $\begin{array}{l}\text { Olive surfaces and brine during spontaneous } \\
\text { and inoculated fermentation }\end{array}$ & Vegetables & {$[11 \bullet]$} \\
\hline 16S RNA (cDNA) & $\begin{array}{l}\text { Wheat flour grown under organic and } \\
\text { conventional farming conditions }\end{array}$ & Doughs & {$[12 \bullet]$} \\
\hline 16S DNA/26S DNA & $\begin{array}{l}\text { Milk kefir grains collected in different } \\
\text { Italian regions }\end{array}$ & Fermented beverages & [13] \\
\hline 16S DNA/ITS DNA & $\begin{array}{l}\text { Samples from spontaneous 'Vino Santo } \\
\text { Trentino' fermentation }\end{array}$ & Fermented beverages & [14] \\
\hline 16S DNA & $\begin{array}{l}\text { Microbiota of Belgian white pudding after } \\
\text { refrigerate storage }\end{array}$ & Meat & [15] \\
\hline 16S DNA & $\begin{array}{l}\text { Rind and core microbiota of Caciotta and } \\
\text { Caciocavallo cheese }\end{array}$ & Dairy and fermented milks & [16] \\
\hline 16S DNA & $\begin{array}{l}\text { Mozzarella cheese made from cow's milk } \\
\text { and produced with different acidification } \\
\text { methods }\end{array}$ & Dairy and fermented milks & [17] \\
\hline 16S DNA/18S DNA & $\begin{array}{l}\text { Naturally fermented cow's milk collected } \\
\text { from Mongol-ethnic families }\end{array}$ & Dairy and fermented milks & [18] \\
\hline 16S DNA & Pico cheese made from raw cow milk & Dairy and fermented milks & [19] \\
\hline 16S DNA & Spoiled hard cheeses during ripening & Dairy and fermented milks & [20] \\
\hline 16S DNA & Brine-salted continental-type cheese & Dairy and fermented milks & [21] \\
\hline 16S DNA & $\begin{array}{l}\text { Poro cheeses manufactured with different } \\
\text { milk }\end{array}$ & Dairy and fermented milks & {$[22]$} \\
\hline 16S DNA & $\begin{array}{l}\text { Herve cheeses from both raw and } \\
\text { pasteurized milk }\end{array}$ & Dairy and fermented milks & [23] \\
\hline 16S RNA (cDNA) & $\begin{array}{l}\text { Piedmont hard cheese made from raw milk: } \\
\text { milk, curd and cheese throughout ripening }\end{array}$ & Dairy and fermented milks & [24] \\
\hline 16S RNA (cDNA) & $\begin{array}{l}\text { Milk, curd and Caciocavallo cheese during } \\
\text { ripening }\end{array}$ & Dairy and fermented milks & {$[25 \bullet]$} \\
\hline 16S RNA (cDNA) & $\begin{array}{l}\text { Milk (from different lactation stages), curd } \\
\text { and Fontina cheese from three different } \\
\text { dairies }\end{array}$ & Dairy and fermented milks & [26] \\
\hline 16S DNA/18S DNA & Fermentation of Pu-erh tea & Fermented beverages & {$[27 \bullet \bullet]$} \\
\hline
\end{tabular}


References and recommended reading

195 Papers of particular interest, published within the review period, have been highlighted as:

196 of special interest

$197 \quad \bullet \quad$ of outstanding interest

198

199 [1]. Ceuppens S, Li D, Uyttendaele M, Renault P, Ross P, Ranst M Van, Cocolin L, Donaghy J: Molecular Methods in Food Safety Microbiology: Interpretation and Implications of

[3]. Połka J, Rebecchi A, Pisacane V, Morelli L, Puglisi E: Bacterial diversity in typical Italian salami at different ripening stages as revealed by high-throughput sequencing of $16 \mathrm{~S}$ rRNA amplicons. Food Microbiol 2015, 46:342-356.

[4]. Greppi A, Ferrocino I, La Storia A, Rantsiou K, Ercolini D, Cocolin L: Monitoring of the microbiota of fermented sausages by culture independent rRNA-based approaches. Int J Food Microbiol 2015, 212:67-75.

[5]. Ferrocino I, Greppi A, La Storia A, Rantsiou K, Ercolini D, Cocolin L: Impact of NisinActivated Packaging on Microbiota of Beef Burgers during Storage. Appl Environ Microbiol 2016, 82:549-559.

[6]. Hultman J, Rahkila R, Ali J, Rousu J, Björkroth KJ: Meat processing plant microbiome and contamination patterns of cold-tolerant bacteria causing food safety and spoilage risks in the manufacture of vacuum-packaged cooked sausages. Appl Environ Microbiol 2015, 81:7088-7097.

[7]. Stellato G, La Storia A, De Filippis F, Borriello G, Villani F, Ercolini D: Overlap of spoilage-associated microbiota between meat and the meat processing environment in 
small-scale and large-scale retail. 2016, 82:4045-4054.

221 [8]. Chaillou S, Chaulot-Talmon A, Caekebeke H, Cardinal M, Christieans S, Denis C, Hélène Desmonts M, Dousset X, Feurer C, Hamon E, et al.: Origin and ecological selection of core and food-specific bacterial communities associated with meat and seafood spoilage. ISME J. 2015, 9:1105-18.

[9]. Elizaquível P, Pérez-Cataluña A, Yépez A, Aristimuño C, Jiménez E, Cocconcelli PS, Vignolo G, Aznar R: Pyrosequencing vs. culture-dependent approaches to analyze lactic

- Selected starter cultures provided more controlled and consistent fermentation and to positively impact the overall table olive quality by affecting the amount of FAAs and phenolic and volatile organic compounds

[12]. Rizzello CG, Cavoski I, Turk J, Ercolini D, Nionelli L, Pontonio E, De Angelis M, De Filippis F, Gobbetti M, Di Cagno R: Organic cultivation of Triticum turgidum subsp. durum is reflected in the flour-sourdough fermentation-bread axis. Appl Environ Microbiol 2015, 81:3192-3204.

- The environment microbiota is an important factor that can affect sourdoughs and it has been found to be closely correlated to the abundance of free and bound phenolic compounds, assessed by means of HPLC

[13]. Garofalo C, Osimani A, Milanović V, Aquilanti L, De Filippis F, Stellato G, Di Mauro S, Turchetti B, Buzzini P, Ercolini D, et al.: Bacteria and yeast microbiota in milk kefir 
grains from different Italian regions. Food Microbiol 2015, 49:123-133.

[14]. Stefanini I, Albanese D, Cavazza A, Franciosi E, De Filippo C, Donati C, Cavalieri D: Dynamic changes in microbiota and mycobiota during spontaneous "Vino Santo Trentino" fermentation. Microb Biotechnol 2016, 9:195-208.

[15]. Cauchie E, Gand M, Kergourlay G, Taminiau B, Delhalle L, Korsak N, Daube G: The use of 254 16S rRNA gene metagenetic monitoring of refrigerated food products for understanding the kinetics of microbial subpopulations at different storage temperatures: the example of white pudding. Int $J$ Food Microbiol 2016, doi:10.1016/j.ijfoodmicro.2016.10.012.

[16]. Calasso M, Ercolini D, Mancini L, Stellato G, Minervini F, Di Cagno R, De Angelis M, Gobbetti M: Relationships among house, rind and core microbiotas during manufacture of traditional Italian cheeses at the same dairy plant. Food Microbiol 2016, 54:115-126.

[17]. Guidone A, Zotta T, Matera A, Ricciardi A, De Filippis F, Ercolini D, Parente E: The microbiota of high-moisture mozzarella cheese produced with different acidification methods. Int J Food Microbiol 2016, 216:9-17.

[18]. Liu W, Zheng Y, Kwok L-Y, Sun Z, Zhang J, Guo Z, Hou Q, Menhe B, Zhang H: Highthroughput sequencing for the detection of the bacterial and fungal diversity in Mongolian naturally fermented cow's milk in Russia. BMC Microbiol 2015, 15:45.

[19]. Riquelme C, Câmara S, Enes Dapkevicius M de LN, Vinuesa P, da Silva CCG, Malcata FX, Rego OA: Characterization of the bacterial biodiversity in Pico cheese (an artisanal Azorean food). Int J Food Microbiol 2015, 192:86-94.

[20]. Bassi D, Puglisi E, Cocconcelli PS: Understanding the bacterial communities of hard cheese with blowing defect. Food Microbiol. 2015, 52:106-118.

[21]. O’Sullivan DJ, Cotter PD, O’Sullivan O, Giblin L, McSweeney PLH, Sheehan JJ: Temporal and spatial differences in microbial composition during the manufacture of a continental-type cheese. Appl Environ Microbiol 2015, 81:2525-2533. 
[22]. Aldrete-Tapia A, Escobar-Ramírez MC, Tamplin ML, Hernández-Iturriaga M: Highthroughput sequencing of microbial communities in Poro cheese, an artisanal Mexican cheese. Food Microbiol 2014, 44:136-141.

[23]. Delcenserie V, Taminiau B, Delhalle L, Nezer C, Doyen P, Crevecoeur S, Roussey D, Korsak N, Daube G: Microbiota characterization of a Belgian protected designation of origin cheese, Herve cheese, using metagenomic analysis. J Dairy Sci 2014, 97:6046-56.

[24]. Alessandria V, Ferrocino I, De Filippis F, Fontana M, Rantsiou K, Ercolini D, Cocolin L: Microbiota of an Italian Grana like cheese during manufacture and ripening unraveled by 16S rRNA-based approaches. Appl Environ Microbiol 2016, 82:3988 -3995.

[25]. De Pasquale I, Di Cagno R, Buchin S, De Angelis M, Gobbetti M: Spatial distribution of the metabolically active microbiota within Italian PDO ewes' milk cheeses. PLoS One 2016, 11:1-23.

- Only a few taxa from the metabolically active microbiota have been related to the proteolysis index in ewe's milk cheese and correlated with the synthesis of volatile compounds.

[26]. Dolci P, De Filippis F, La Storia A, Ercolini D, Cocolin L: rRNA-based monitoring of the microbiota involved in Fontina PDO cheese production in relation to different stages of cow lactation. Int J Food Microbiol 2014, 185:127-35.

[27]. Zhao M, Zhang D-L, Su X-Q, Duan S-M, Wan J-Q, Yuan W-X, Liu B-Y, Ma Y, Pan Y-H: An integrated metagenomics/metaproteomics investigation of the microbial communities and enzymes in solid-state fermentation of pu-erh tea. Sci Rep 2015, 5:10117.

-. Proteobacteria have been found to be responsible for the characteristics of Post-fermented Puerh tea (also known as Chinese tea), which was investigated by coupling amplicon HTS with a metaproteomic approach

[28]. Santamaria M, Fosso B, Consiglio A, De Caro G, Grillo G, Licciulli F, Liuni S, Marzano M, Alonso-alemany D, Valiente G, et al:: Reference databases for taxonomic assignment in 
metagenomics. Brief Bioinform 2012, 13:682-695.

[29]. Tang J, Iliev ID, Brown J, Underhill DM, Funari VA: Mycobiome : Approaches to analysis of intestinal fungi. $J$ Immunol Methods 2015, 421:112-121.

[30]. Kurtzman CP, Robnett CJ: Identification and phylogeny of ascomycetous yeasts from analysis of nuclear large subunit (26S) ribosomal DNA partial sequences. Antonie van Leeuwenhoek, Int J Gen Mol Microbiol 1998, 73:331-371.

[31]. Wang C, García-Fernández D, Mas A, Esteve-Zarzoso B: Fungal diversity in grape must and wine fermentation assessed by massive sequencing, quantitative PCR and DGGE. Front Microbiol 2015, 6:1-8.

[32]. Stellato G, De Filippis F, La Storia A, Ercolini D: Coexistence of lactic acid bacteria and potential spoilage microbiota in a dairy-processing environment. Appl Environ Microbiol 2015, 22:7893-7904.

[33]. Pinu FR: Early detection of food pathogens and food spoilage microorganisms: Application of metabolomics. Trends Food Sci Technol 2016, 54:213-215.

[34]. Parente E, Cocolin L, De Filippis F, Zotta T, Ferrocino I, O’Sullivan O, Neviani E, De Angelis M, Cotter PD, Ercolini D: FoodMicrobionet: A database for the visualisation and exploration of food bacterial communities based on network analysis. Int $J$ Food Microbiol 2016, 219:28-37.

- This paper describe an easy-to-use tool for the visualization and comparison of microbiota in diverse foodstuffs. Users can easily extract subsets of samples for the food matrix of interest, visualize them in a network and/or use them in comparative studies.

[35]. Langille MGI, Zaneveld J, Caporaso JG, McDonald D, Knights D, Reyes J a, Clemente JC, Burkepile DE, Vega Thurber RL, Knight R, et al:: Predictive functional profiling of microbial communities using 16S rRNA marker gene sequences. Nat Biotechnol 2013, 31:814-21.

[36]. Eren AM, Maignien L, Sul WJ, Murphy LG, Grim SL, Morrison HG, Sogin ML: Oligotyping: Differentiating between closely related microbial taxa using 16S rRNA 
gene data. Methods Ecol Evol 2013, 4:1111-1119.

[37]. Berni Canani R, Sangwan N, Stefka AT, Nocerino R, Paparo L, Aitoro R, Calignano A, Khan A a, Gilbert J a, Nagler CR: Lactobacillus rhamnosus GG-supplemented formula expands butyrate-producing bacterial strains in food allergic infants. ISME $J 2015$, 10:1-9.

[38]. Fisher JC, Levican A, Figueras MJ, McLellan SL: Population dynamics and ecology of Arcobacter in sewage. Front Microbiol 2014, 5:1-9.

[39. De Filippis, F, Genovese A, Ferranti P, Gilbert JA, Ercolini D: Metatranscriptomics reveals temperature-driven functional changes in microbiome impacting cheese maturation rate. Sci Rep 2016, 6:1-12.

-. The study has clearly shown that the ripening temperature can significantly affect the gene expression, with a clear correlation with the metabolomic profiles of volatile organic compounds during cheese ripening. NOT CLEAR

[40]. Lessard M-H, Viel C, Boyle B, St-Gelais D, Labrie S: Metatranscriptome analysis of fungal strains Penicillium camemberti and Geotrichum candidum reveal cheese matrix breakdown and potential development of sensory properties of ripened Camemberttype cheese. BMC Genomics 2014, 15:235.

[41]. Monnet C, Dugat-Bony E, Swennen D, Beckerich J-M, Irlinger F, Fraud S, Bonnarme P: Investigation of the activity of the microorganisms in a reblochon-style cheese by metatranscriptomic analysis. Front. Microbiol. 2016, 7:536.

[42]. Dugat-Bony E, Straub C, Teissandier A, Onésime D, Loux V, Monnet C, Irlinger F, Landaud S, Leclercq-Perlat M-N, Bento P, et al.: Overview of a surface-ripened cheese community functioning by meta-omics analyses. PLoS One 2015, 10:e0124360.

- This study has clearly shown that the application of a multi-omics approach is able to furnish an overview of the cheese maturation process and to obtain a better understanding of the metabolic activities of the different community members and their possible interactions.

[43]. Yang X, Noyes NR, Doster E, Martin JN, Linke LM, Magnuson RJ, Yang H, Geornaras I, Woerner DR, Jones KL: Use of metagenomic shotgun sequencing technology to detect 
foodborne pathogens within the microbiome of the beef production chain. Appl Environ Microbiol 2016, 82:2433-2443.

[44]. Leonard SR, Mammel MK, Lacher DW, Elkins CA: Application of metagenomic

[47]. Nalbantoglu U, Cakar A, Dogan H, Abaci N, Ustek D, Sayood K, Can H: Metagenomic analysis of the microbial community in kefir grains. Food Microbiol 2014, 41:42-51.

[48]. Escobar-Zepeda A, Sanchez-Flores A, Quirasco Baruch M: Metagenomic analysis of a Mexican ripened cheese reveals a unique complex microbiota. Food Microbiol 2016, 57:116-127.

[49]. Nayfach S, Pollard KS: Leading edge perspective toward accurate and quantitative comparative metagenomics. 2016, Cell 116:1103-1116.

[50]. Scholz M, Ward DV, Pasolli E, Tolio T, Zolfo M, Asnicar F, Truong DT, Tett A, Morrow AL, Segata N: Strain-level microbial epidemiology and population genomics from shotgun metagenomics. Nat Methods 2016, 13:435-438.

[51]. Eren AM, Esen ÖC, Quince C, Vineis JH, Morrison HG, Sogin ML, Delmont TO: Anvi’o: an advanced analysis and visualization platform for 'omics data. PeerJ 2015, 3:e1319.

[52]. Armengaud J, Hartmann EM, Bland C: Proteogenomics for environmental microbiology. Proteomics 2013, 13:2731-2742.

[53]. Wilmes P, Heintz-Buschart A, Bond PL: A decade of metaproteomics: Where we stand 
and what the future holds. Proteomics 2015, 15:3409-3417.

388 [54]. Soggiu A, Piras C, Mortera SL, Alloggio I, Urbani A, Bonizzi L, Roncada P: Unravelling the effect of clostridia spores and lysozyme on microbiota dynamics in Grana Padano cheese: A metaproteomics approach. J Proteomics 2015, 147:21-27. 